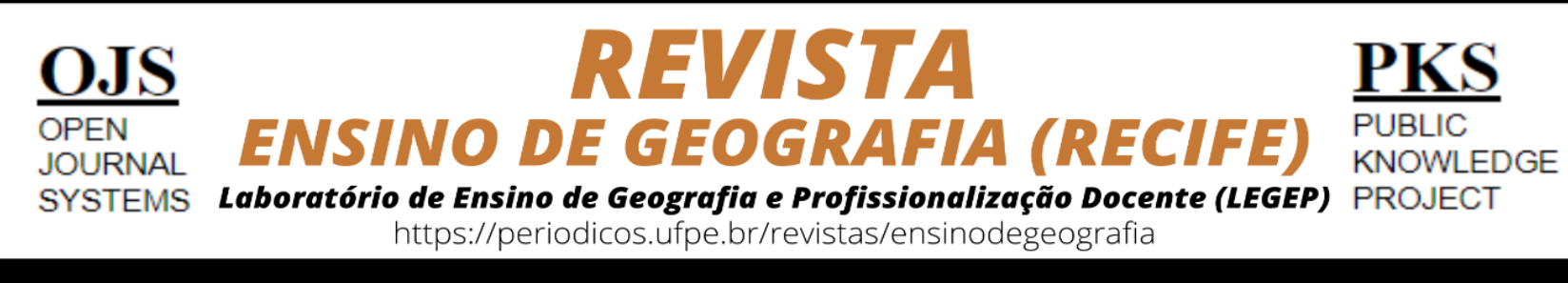

\title{
TRANSFORMAÇÃO DA PAISAGEM NO ENTORNO ESCOLAR: MEMÓRIAS E NARRATIVAS DE MORADORES E PROFESSORES
}

\author{
Cristian Roberto Antunes de Oliveira ${ }^{1}$, Terciane Ângela Luchese ${ }^{2}$, Lucia Ceccato de Lima ${ }^{3}$
}

\begin{abstract}
${ }^{1}$ Doutorando em Educação pela Universidade de Caxias do Sul (2019). Mestre em Educação (UNIPLAC) 2017. Licenciado em Geografia (UNIPLAC) 2014. Docente da Educação Básica no Sistema Municipal da Educação de Lages e Professor Universitário no Departamento de Ensino de Geografia do Centro Universitário UNIFACVEST. E-mail: cristian.antunes8@hotmail.com.Orcid: http://orcid.org/0000-0002-5526-6274.

${ }^{2}$ Doutora em Educação pela UNISINOS, professora do Programa de Pós-Graduação em Educação, Linha de Pesquisa História e Filosofia da Educação da Universidade de Caxiasdo Sul (Caxiasdo Sul, RS, Brasil).E-mail: taluches@ucs.br. Orcid: http://orcid.org/0000-0002-6608-9728.

${ }^{3}$.Doutora em Engenharia Ambiental pela Universidade Federal de Santa Catarina (UFSC - 2007). Docente Pesquisadora (Programa de Pós Graduação em Educação) - Universidade do Planalto Catarinense: Lages, SC, BR. Email: ceccato@gmail.com. Orcid: http://orcid.org/0000-0002-0760-5913.
\end{abstract}

Artigo recebido em 09/09/2021 e aceito em 23/10/2021

\section{RESUMO}

Este artigo foi produzido a partir da pesquisa realizada no Mestrado em Educação do Programa de PósGraduação da Universidade do Planalto Catarinense (UNIPLAC), alicerçado por uma análise da transformação da paisagem no entorno de uma escola da cidade de Lages/SC. O questionamento que orienta a pesquisa parte do princípio de que é necessário construir uma consciência da importância da escola na formação social, política, histórica e geográfica do bairro Santa Clara, em Lages/SC, que aqui se toma esse espaço geográfico como ponto de partida, a fim de fazer uma análise das transformações da paisagem e suas implicações no entorno escolar, a partir do uso e ocupação do bairro. Nessa perspectiva, observamos a dinâmica da organização do espaço geográfico, que se constitui como ponto de referência geográfico e social para a comunidade. Para o desenvolvimento do estudo foi escolhida a pesquisa bibliográfica e documental com o trabalho de campo, ficando definida a abordagem qualitativa. Após esses momentos, optou-se, como procedimento metodológico, pela realização de entrevistas narrativas, contextualizando as percepções dos moradores e professores sobre o espaço vivido na construção de um olhar espacial crítico do lugar.

Palavras-chave: Transformação da paisagem; Escola; Bairro; Lugar; Espaço geográfico. 


\title{
LANDSCAPE TRANSFORMATION AROUND THE SCHOOL: MEMORIES AND NARRATIVES OF RESIDENTS AND TEACHERS
}

\begin{abstract}
This paper was written based on research developed for the Master of Education's degree in the graduation program from the University of Planalto Catarinense, which was characterized by an analysis of the landscape transformation around a school in the city of Lages/SC. The research question for this study is based on the principle that it is necessary to build an awareness regarding the importance of school for the social, political, historical and geographical formation of the Santa Clara neighborhood, in Lages/SC, which is taken in this study as the geographical space, the starting point, for the analysis of the landscape transformations and their implications around the school, based on the use and occupation of the neighborhood. In that regard, we observed the organization dynamics of the geographical space, which is taken as a geographical and social point of reference for the community. To develop this study, we chose document and literature review and field research, based on the qualitative approach. Subsequently, we opted for narrative interviews as the methodological procedure, contextualizing the residents' and teachers' perspectives concerning the lived space in forming a critical spatial perception of the place.
\end{abstract}

Keywords: Landscape transformation. School. Neighborhood. Place. Geographical space.

\section{TRANSFORMACIÓN DEL PAISAJE EN EL ENTORNO ESCOLAR: MEMORIAS Y NARRATIVAS DE VECINOS Y PROFESORES}

\begin{abstract}
RESUMEN
Este artículo fue producido a partir de la investigación realizada en la Maestría en Educación del Programa de Postgrado de la Universidad del Planalto Catarinense, fundamentado por un análisis de la transformación del paisaje en los alrededores de una escuela de la ciudad de Lages/SC. El asunto que orienta la investigación parte del principio de que es necesario construir una consciencia sobre la importancia de la escuela en la formación social, política, histórica y geográfica del barrio Santa Clara, Lages/SC, aquí considerada como el espacio geográfico, el punto de partida, para analizar las transformaciones del paisaje y sus implicaciones en el entorno escolar, a partir del uso y ocupación del barrio. En esta perspectiva, observamos la dinámica de la organización del espacio geográfico, que se constituye como punto de referencia geográfico y social para la comunidad. Para desarrollar este estudio se combinó la investigación bibliográfica y documental con el trabajo de campo, definida por el método cualitativo. A continuación, el procedimiento metodológico adoptado fue llevar a cabo entrevistas narrativas, contextualizando las percepciones de los vecinos y profesores sobre el espacio vivido en la construcción de una perspectiva espacial crítica del lugar.
\end{abstract}

Palabras clave: Transformación del paisaje. Escuela. Barrio. Lugar. Espacio Geográfico.

\section{INTRODUÇÃO}

Todo lugar carrega consigo sua história, e com as cidades, bairros, ruas e praças não poderia ser diferente. A memória é ponto fundante para que a identidade e o sentimento de pertencimento tranversalizem os resultados da percepção de fatores sociais e geográficos de onde as pessoas estão 
inseridas. Este estudo parte do princípio de que é necessário construir uma consciência da importância da escola na formação social, política, histórica e geográfica do bairro Santa Clara, em Lages/SC, e aqui se toma esse espaço geográfico como ponto de partida, a fim de fazer uma análise sobre as transformações da paisagem.

O bairro teve sua origem como um loteamento, implantado no final dos anos 1960, por empresários da região serrana de Santa Catarina. Inicialmente, os lotes foram comercializados sem que o loteamento tivesse infraestrutura urbana. Naquela época, os moradores contavam apenas com a escola isolada, fundada em 1969. O bairro ${ }^{1}$ é, ainda hoje, considerado um dos mais vulneráveis da cidade de Lages/SC.

No estudo da transformação da paisagem com o processo de urbanização ou ocupação, cabe refletirmos que esse espaço deve ser pensado como um produto histórico, e que revela as práticas sociais das pessoas que nele vivem. Esse espaço geográfico pode ser lido e entendido de diferentes formas e, por isso, a percepção dos sujeitos é de fundamental importância. Ainda assim, nesse movimento urbano, determinados fatores contribuem fortemente para o uso e a ocupação do solo de forma desordenada. Como fatores indissociáveis da transformação da paisagem, destacamos a falta de planejamento urbano, a construção inadequada em áreas de preservação ambiental, a vulnerabilidade social e o uso exacerbado de recursos naturais.

Diante do exposto, o objetivo deste artigo é apresentar uma análise da transformação da paisagem do entorno escolar do bairro Santa Clara, a partir da percepção de moradores e professores. Compreender o papel da escola no processo de formação do bairro é reconhecer a importância desse educandário ao longo de sua formação, é perceber como esses sujeitos, imbricados nesse lugar, se percebem e se reconhecem como parte dessa história. A escola é a única do bairro, e sua fundação ocorreu no mesmo ano (1969) em que o local passou a receber os seus primeiros habitantes, sendo, desde então, o principal ponto de referência dos moradores.

Para o desenvolvimento deste estudo foi escolhida a pesquisa bibliográfica e documental com o trabalho de campo, definindo-se pela abordagem qualitativa. Após esses momentos, optou-se como procedimento metodológico a escolha pelas entrevistas narrativas. As entrevistas narrativas foram

\footnotetext{
${ }^{1}$ A paisagem do bairro foi bastante alterada em decorrência do fluxo populacional migratório, pois muitos moradores que ali se estabeleceram vinham de cidades limítrofes do estado, como Campo Belo do Sul, Capão Alto, Cerro Negro, e, além de ocuparem áreas inadequadas para a construção de suas moradias, uma vez que eram terrenos destinados a áreas de preservação ambiental, também alteraram significativamente a paisagem natural (CORREIO LAGEANO, 2004). 
adotadas como um instrumento que deu voz aos sujeitos. Por meio delas, ouvimos dois professores e dois moradores, os critérios de inclusão foram os seguintes: professores efetivos na Unidade de Escolar, com no mínimo cinco anos de atuação docente na escola, e moradores que residem na comunidade no mínimo há dez anos. "Nada melhor do que ouvir as pessoas, escutar suas lembranças, comparar suas falas, percebendo diferenças e semelhanças entre elas” (ALMEIDA; SILVA, 2011, p. 7). Para conduzir as entrevistas, tomamos como procedimento a elaboração de um roteiro, com nove perguntas, que foram todas foram gravadas em áudio e, posteriormente, transcritas para análise.

No roteiro, as perguntas concentraram-se em três grandes eixos, que são: a) como está organizada a dinâmica espacial do bairro na atualidade e como foi outrora; b) questionamentos sobre suas memórias do espaço geográfico do entorno escolar e quais foram as transformações mais evidentes; e, por fim, c) os aspectos afetivos dos entrevistados com o bairro, com a escola, ou seja, o sentimento de pertencimento. Suas memórias foram, posteriormente, indexadas com as produções científicas.

Vale ressaltar que o artigo está estruturado em duas partes, sendo que a primeira traz uma abordagem conceitual das categorias principais do estudo, a partir do espaço geográfico, do território, da paisagem e do lugar, em especial. Na sequência, apresentamos o contexto histórico e geográfico do bairro por meio das fontes documentais (registros fotográficos do acervo dos moradores) e os resultados da pesquisa com as entrevistas narrativas ${ }^{2}$ dos professores e moradores, junto com a análise e a conclusão, perpassando por elementos fundantes da transformação da paisagem.

\section{ESPAÇO GEOGRÁFICO E TRANSFORMAÇÃO DA PAISAGEM: UMA ABORDAGEM CONCEITUAL}

A ciência geográfica preocupa-se em estudar diferentes processos que ocorrem na sociedade, sendo assim, focar na relação dos aspectos da natureza, transformação da paisagem, espaço geográfico, meio ambiente, fenômenos de ordem cultural, entre outros, são correntes que se centram no escopo teórico dessa ciência. No que tange ao espaço geográfico e à transformação da paisagem, existem interferências necessárias, que conduzem a uma visão holística, na qual o sujeito se reconhece como um ser histórico-

\footnotetext{
${ }^{2}$ A realização das entrevistas narrativas foi autorizada pelo Comitê de Ética e Pesquisa da UNIPLAC, sob o registro do CAAE: 86632918.6.0000.5368. 
social capaz de atuar na modificação do ambiente, se reconhecer nele, pertencer e interferir nele por meio de suas atitudes na transformação do espaço.

A formação de um espaço geográfico se constitui de diferentes formas, sendo permeado por forças internas e externas que influenciam na transformação do lugar. Por isso, alguns desses elementos são imprescindíveis para que se conheça a história de um determinado lugar - neste caso, o bairro -; entre eles existe a dinâmica que envolve a transformação da paisagem, que perpassa por elementos da natureza e pela intervenção humana nesse processo.

Na visão de Santos (2004), o espaço é considerado um fator de transformação social e cultural, contudo, não é formado apenas pelas coisas, pelos objetos geográficos, naturais e artificiais presentes na natureza. Além do meio natural e artificial, o espaço geográfico também é constituído pela força da sociedade e de sua organização, bem como é atravessado por relações de poder. Com isso, a questão ambiental passa a ganhar força e preocupação, pois emergem, nesse momento, diferentes processos, entre eles os modos de produção e organização do capital, que passam a influenciar, em detrimento da "sobrevivência", a devastação nos espaços que, antes, eram preservados.

O estudo da paisagem não pode ser visto somente do ponto de vista natural, mas, sim, de sua totalidade. Com as mudanças nas relações de espaço e tempo, avançou-se para o meio técnico-científico informacional, e a paisagem, por sua vez, tornou-se mais científica e técnica, ao passo que o espaço se tornou informacional (SANTOS, 1994).

Relph (1999, p. 156) entende que "lugar significa muito mais que o sentido geográfico de localização. Não se refere a objetos e atributos das localizações, mas a tipos de experiências e envolvimento com o mundo, a necessidade de raízes e segurança”. Também é por meio do lugar que expressamos nossos sentimentos, pois construímos nele memórias, e estas consolidam o sentimento de pertencimento que nos faz reviver emoções e relações com o ambiente em que estamos inseridos. A paisagem é o meio que revela os processos de ocupação do lugar, nas suas diferentes manifestações culturais. Cavalcanti (2004, p. 100) entende que:

[...] na formação do raciocínio geográfico, o conceito de paisagem aparece no meu entendimento, no primeiro nível de análise do lugar, estando estreitamente com este conceito. É pela paisagem, vista em seus determinantes e em suas dimensões, que vivencia empiricamente um primeiro nível de identificação com o lugar.

É nesse espaço instituído lugar que se manifestam as relações locais e que, por consequência, estão imbricadas com o sentimento de pertencimento, e é nele que percebemos que paisagem e lugar são 
categorias geográficas que caminham juntas. O espaço geográfico é complexo em sua organização, pois trata da relação do homem com a natureza e de suas diversas manifestações.

Dessa forma, o espaço é um misto entre o social e o físico. É por meio do espaço que outras categorias importantes da geografia, se conectam, por exemplo: o lugar, o espaço, a paisagem e o território. A leitura do espaço é o meio pelo qual podemos compreender a relação do homem com o processo de modificação da natureza; o espaço é formado por um conjunto de fatores de ordem social e natural, sendo, por diversas vezes, modificado pela força do trabalho.

Santos (1994, p. 10) define epistemologicamente o espaço da seguinte forma: "O espaço não é nem uma coisa, nem um sistema de coisas, senão uma realidade relacional: coisas e relações juntas"; sendo assim, "Eis por que sua definição não pode ser encontrada senão em relação a outras realidades: a natureza e a sociedade, mediatizadas pelo trabalho". Nesse movimento mediatizado, podemos entender que a relação da composição do espaço com o global se dá a partir da compreensão do todo, ou seja, de um espaço territorial de escala local, regional, nacional e global.

Gomes (2000, p. 172) aponta três características que definem o "espaço geográfico": 1) o espaço é sempre uma extensão fisicamente constituída, concreta, material, substantiva; 2) o espaço compõe-se pela dialética entre a disposição das coisas e as ações ou práticas sociais; 3) a disposição das coisas materiais tem uma lógica ou coerência. A Figura 1 demostra a relação do espaço com o que está em seu entorno. Dessa forma, o espaço é o meio pelo qual as demais categorias se interligam para explicar conceitos geográficos e suas manifestações da relação sociedade/natureza. Santos (2004, p. 18) afirma que “o espaço é definido como um conjunto indissociável de sistemas de objetos e de sistemas de ações”. O espaço é o movimento das relações físicas e sociais do que acontece no planeta. 


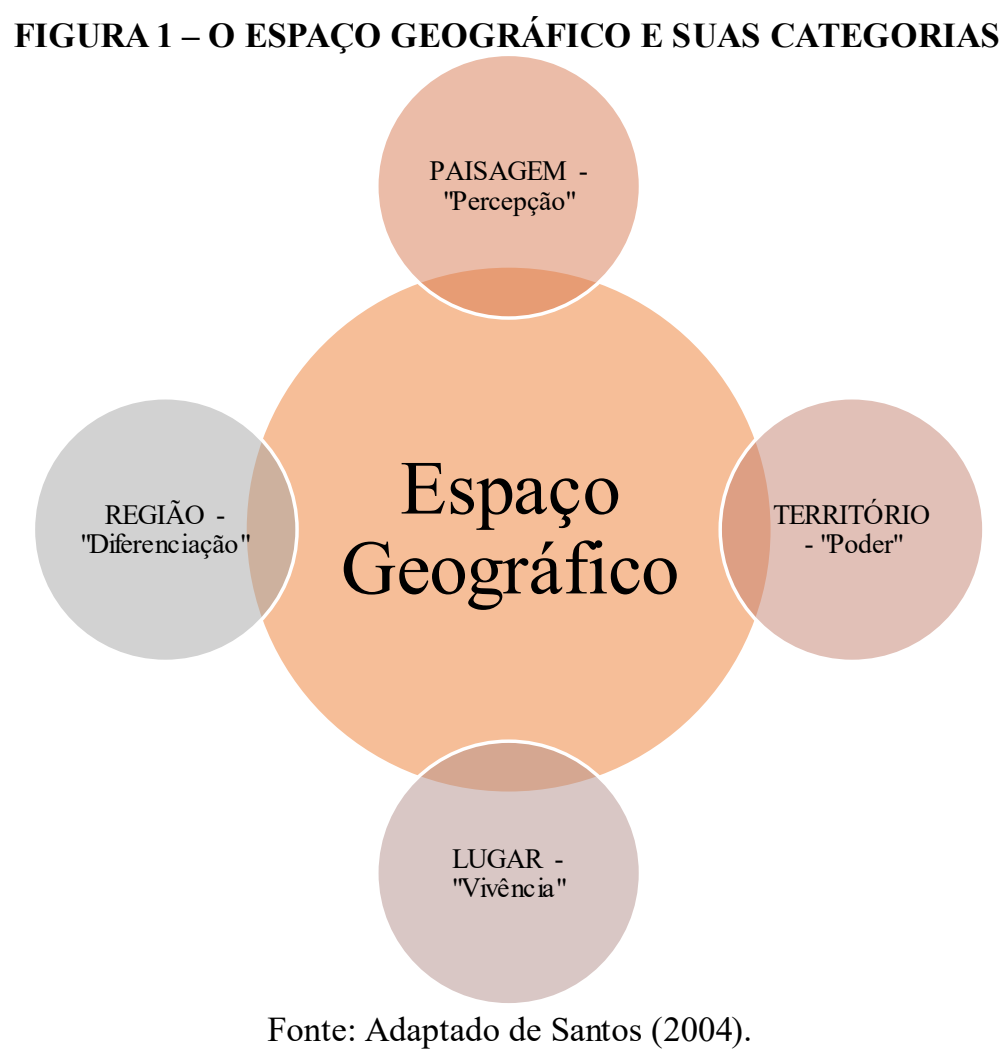

Nessa dialética conceitual, vale ressaltar que, para Andrade (2004, p. 19), "o conceito de território não deve ser confundido com o de espaço ou de lugar, estando muito ligado à ideia de domínio ou gestão de determinada área”. Com isso, território e poder se relacionam a partir do estabelecimento da relação com o lugar e da forma como isso ocorre na dinâmica da ocupação do espaço. "A formação de um território dá às pessoas que nele habitam a consciência de sua participação, provocando o sentido da territorialidade que, de forma subjetiva, cria uma consciência de confraternização sobre elas" (ANDRADE, 2004, p. 20).

Perceber os elementos naturais e sociais do ambiente em que estamos inseridos é a forma pela qual podemos ajudar na construção de um espaço melhor para se viver. Fernandes (2001, p. 95) entende que as "percepções do mundo real ou do contexto social são registradas e conservadas na memória na forma de imagens geradas a partir das experiências mantidas com o meio social e natural". As experiências do mundo real intervêm de forma direta na construção da memória do espaço local. Perceber o ambiente é estar conectado com as mudanças que ocorrem o tempo todo em sua formação, é possível por meio de uma percepção ambiental influenciar de forma positiva na ocupação do lugar, bem como do que ocorre em seu entorno. 
A percepção do mundo é feita por meio de todos os sentidos, os quais variam de acordo com os contextos nos quais as pessoas estão inseridas. O mundo percebido pelos olhos é puramente uma relação com o objeto. A percepção e a imagem são dinâmicas no tempo e no espaço, a compreensão do meio urbano muda concomitantemente com a idade, o sexo, a educação, a cultura, a erudição, a classe social, a economia, a política, a religião, a individualidade, as preferências, as atitudes, valores e as atribuições do meio ambiente (ADDISON, 2003).

A cultura é constituída pelo conjunto dos saberes, fazeres, regras, normas, proibições, estratégias, crenças, ideias, valores e mitos que se transmite de geração em geração, se reproduz em cada indivíduo, controla a existência da sociedade e mantém a complexidade psicológica e social. O mundo percebido, muito mais dinâmico do que podemos imaginar, só é mundo notado pela existência inseparável desse multiplicar de fenômenos de percepção e inserção do homem como ser-no-mundo-com-os-outros (MERLEAU-PONTY, 1990).

Retomamos agora, a fim de esculpir um conceito mais profundo sobre paisagem, a constituição do termo que é muito mais antiga do que se pode imaginar, sendo que a mesma é empregada há mais de mil anos por meio da palavra alemã landschaft (paisagem) e, desde então, vem tendo uma dinâmica linguística muito significativa (TROLL, 1997). Por isso, apresentamos a seguir a Figura 2, que traz, em sua organização, diferentes conceitos, definidas por distintas escolas geográficas. 
FIGURA 2 - CONCEITOS DE PAISAGEM

Escola Germânica: foram apresentados novos conceitos sobre paisagem, trabalhando em uma visão geográfica, a partir de um novo método de trabalho baseado na cartografia geomorfológica. Essa escola introduziu também o conceito da paisagem como categoria científica e a compreendeu até os anos de 1940, como um conjunto de fatores naturais e humanos.
Escola Francesa: Christofoletti (1999) afirma que La Blache considerou como elementos básicos, na organização e desenvolvimento dos estudos geográficos: as características significativas dos pays e regiões, os componentes da natureza e os originários das atividades humanas (virada do século XX). Dessa forma, Guerra (2006) complementa que o termo "região" foi, durante um longo tempo, o pilar da geografia francesa, aplicando-se tanto a conjuntos físicos, estruturais ou climáticos quanto aos domínios caracterizados pela sua vegetação.
$\mathrm{Na}$ antiga União Soviética: caracterizou-se por ser uma escola fechada, cientificamente, em relação às demais, e pode-se dizer que Dokoutchaev, em 1912, trouxe uma nova abordagem com relação aos elementos da natureza, definindo o Complexo Natural Territorial (CNT), no qual inclui os processos físicos, químicos e bióticos, colocando a vegetação como diferenciadora nas tipologias das unidades de paisagem e o solo como produto da interação entre o relevo, o clima e a vegetação.
Na escola Anglo-americana: durante os anos de 1940, nos Estados Unidos, substituiu o termo landscape, que estava, até então, em uso nesse país sob influência da geografia alemã (Carl Sauer), pela ideia da "região" (Richard Hartshorne), sendo esta um conjunto de variáveis abstratas deduzidas da realidade da paisagem e da ação humana (SCHIER, 2003). A paisagem era analisada sob a perspectiva da evolução do relevo, e teve como destaque trabalhos de Grove Karl (1880) e de William Morris Davis (1899).

Fonte: Elaborada pelos pesquisadores (2021).

O estudo da categoria paisagem está intrinsicamente ligado ao lugar ao qual ela se manifesta e expressa suas transformações. “A paisagem é história congelada, mas participa da história viva. São suas formas que realizam, no espaço, as funções sociais” (SANTOS, 2004, p. 107). A paisagem é evidenciada no meio natural e faz parte da constituição da história do espaço geográfico, pois suas transformações constituem a identidade do lugar. Bolós (1981, p. 55) define o conceito de paisagem da seguinte forma:

A paisagem como "uma área geográfica, unidade espacial, cuja morfologia agrega uma complexa inter-relação entre a litologia, estrutura, solo, fauna e flora, sob ação constante da sociedade, que transforma". Sendo que o espaço geográfico é onde as intervenções da sociedade alteram-se ao longo do tempo e sua dinâmica e evolução são determinadas por processos históricos e naturais.

As discussões acerca do conceito dessa categoria tão importante para a geografia tornaram o processo de compreensão dissociável do senso comum. Aqui cabe ressaltar a contribuição de La Blache (1982, p. 89), que afirmou que paisagem é aquilo que “o olho abarca com o olhar". Esse foi 
um dos primeiros entendimentos sobre o conceito de paisagem. Sabe-se, porém, compreendê-la é analisar outros elementos fundamentais na modificação e constituição do espaço natural e social.

Quando observamos as "forças" que alteram o espaço, percebemos que a transformação da paisagem e sua própria identidade se dão por meio de processos naturais e históricos, o que evidencia a característica do lugar. Com essa modificação constante, a paisagem nos revela a memória de um espaço vivido e, por consequência, transformado/ocupado. A paisagem evidencia, ainda, elementos importantes da ocupação de um lugar e características dos sujeitos que fizeram parte dessa transformação, alterando, então, o natural e impregnando/constituindo o cultural. A paisagem não é homogênea; sua modificação é constante, como refere Santos (2008, p. 65):

A paisagem é um conjunto heterogêneo de formas naturais e artificiais; é formada por frações de ambas, seja quanto ao tamanho, volume, cor, utilidade, ou por qualquer outro critério. A paisagem é sempre heterogênea. A vida em sociedade supõe uma multiplicidade de funções e quanto maior o número destas, maior a diversidade de formas e de atores. Quanto mais complexa a vida social, tanto mais nos distanciamos de um mundo natural e nos endereçamos a um mundo artificial.

Trabalhar esses conceitos dentro da escola é de fundamental importância para que os estudantes reconheçam, por meio dessa categoria, o processo histórico e social que se tem com os fluxos de urbanização e como ele se relaciona com a ocupação/transformação do espaço. Compreender esses conceitos torna os estudantes críticos e atentos à história local de seu bairro, o que lhes confere discernimento para entender as razões da alteração da paisagem como um fenômeno incontrolável pelas caracterizações do processo de urbanização que acontece em todos os espaços urbanos, mesmo aqueles que ainda preservam características rurais, como é o caso do bairro Santa Clara, locus da pesquisa.

O espaço geográfico é o conceito balizador da Geografia, é pensado como um todo uno e múltiplo, aberto a múltiplas conexões. Cavalcanti (2004, p. 43) alerta que "caberia ao ensino trazer a 'paisagem' para o universo do aluno, para o lugar vivido por ele, o que quer dizer trazer a paisagem conceitualmente como um instrumento que o ajude a compreender o mundo em que vive".

A paisagem é capaz de revelar a forma como as sociedades se organizam no entorno de um determinado espaço. Ela é, em essência, a categoria que expressa, de forma visual, elementos naturais e sociais que fizeram parte da modificação de um determinado espaço geográfico. 


\section{CONTEXTO HISTÓRICO E GEOGRÁFICO DO BAIRRO A PARTIR DA TRANSFORMAÇÃO DA PAISAGEM}

A fim de situar o contexto histórico e geográfico do bairro Santa Clara ${ }^{3}$, iniciamos por Lages, município localizado na mesorregião serrana de Santa Catarina e, principal da região, com a maior área em extensão territorial do estado, com $2.632 \mathrm{~km}$. O município é constituído de três distritos: Lages, Índios e Santa Terezinha do Salto, e assim permanece desde a divisão territorial de 2003.

Fundada em 1766 pelo bandeirante paulista Antônio Correia Pinto de Macedo, Lajes ${ }^{4}$ servia inicialmente como estalagem para a rota comercial entre o Rio Grande do Sul e São Paulo, principalmente na passagem do gado dos campos gaúchos para abastecer os trabalhadores da extração de ouro em Minas Gerais. Durante mais de um século, as trocas mercantis realizadas entre o planalto serrano e o litoral catarinense eram transportadas por tropeiros. O principal produto do planalto era o gado, e do litoral vinham os derivados da cana-de-açúcar, da mandioca e o sal. Parte desse caminho ainda existe - às margens da BR 282 -, e é conhecido como a Rota dos Tropeiros que ainda sobrevivem ao tempo (SANTA CATARINA, 2007).

Correia Pinto batizou-a assim devido à abundância da pedra laje na região, mas o nome original era Nossa Senhora dos Prazeres dos Campos das Lajens. Instituída vila pelo governador de São Paulo Luís António de Sousa Botelho Mourão, Lages teve seu território transferido da capitania de São Paulo para a capitania de Santa Catarina, por D. João VI, em 9 de setembro de 1820. Décadas após o fim da Revolução Farroupilha, teve seu primeiro paço municipal edificado entre 1898 e 1902. É considerada polo da Região Serrana, tendo aproximadamente 160 mil habitantes (IBGE, 2010). A Figura 3, apresenta o Mapa da Localização da Cidade de Lages/SC, considerando sua espacialidade em âmbito local, estadual e nacional.

\footnotetext{
${ }^{3}$ O histórico do bairro Santa Clara foi baseado no jornal Correio Lageano, da cidade de Lages/SC, no qual foi publicado, entre os anos de 1998 e 2004, reportagens sobre a história dos bairros, por meio de depoimentos de alguns moradores locais.

${ }^{4}$ Em 25 de maio de 1860, foi elevada à categoria de cidade e chamada de Campos de Lajens devido à abundância de Pedra Laje (arenito) em certos pontos da região. Em 1960, por decreto assinado pelo prefeito Vidal Ramos Júnior, ficou estabelecido o topônimo de Lages com “G”. Lages foi colonizada por paulistas e espanhóis, além de outros migrantes ao longo de sua história (SANTA CATARINA, 2007). 


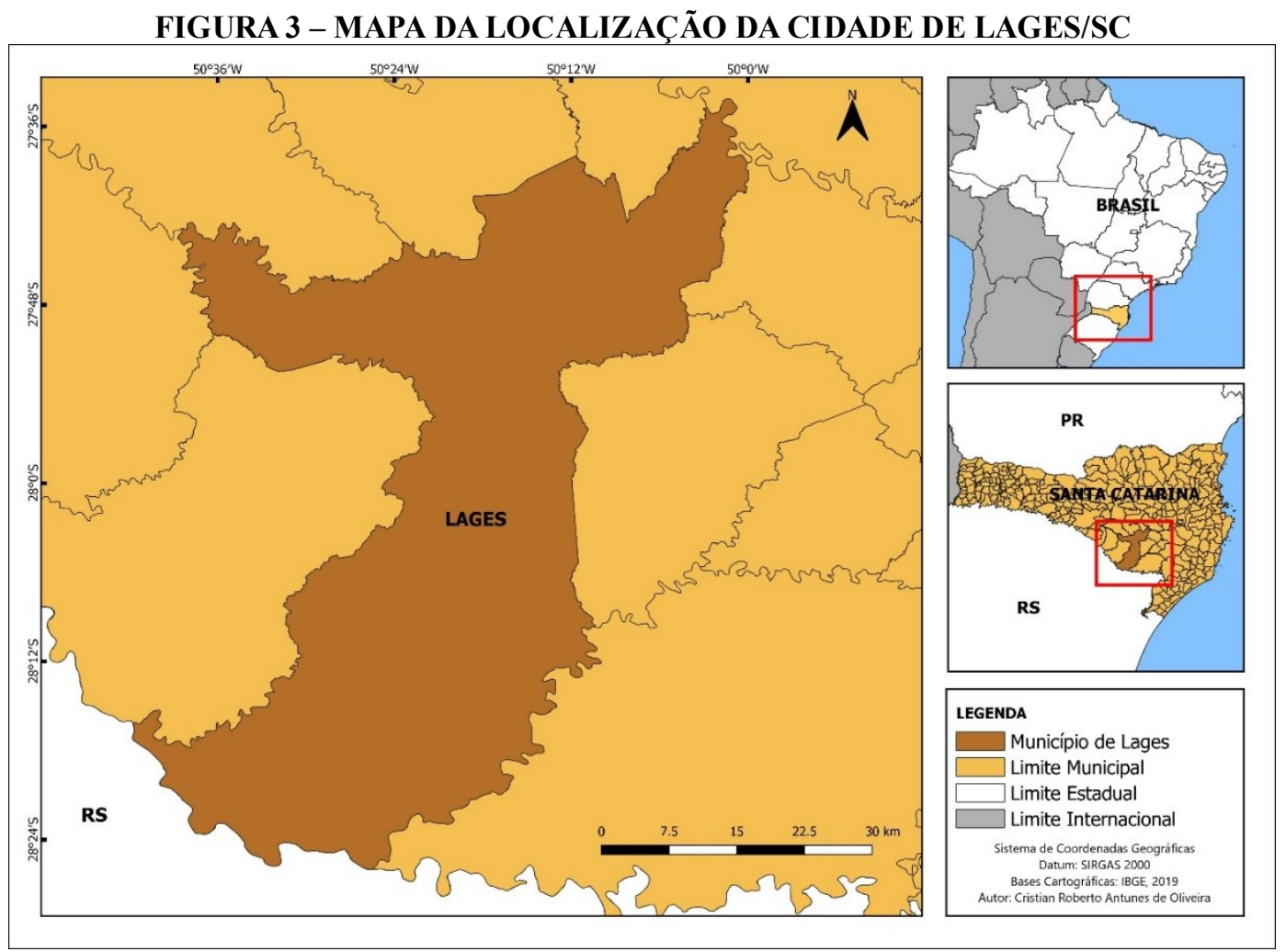

Fonte: Dados extraídos de $\operatorname{IBGE}^{5}$ (2019).

Segundo o Correio Lageano (1998), o bairro teve sua origem no loteamento Santa Clara, implantado, no final dos anos 1960, pelos empresários Ary Heinzen, Aldo Fronza e Noberto da Silveira. Portanto, o território do Santa Clara antigamente fazia parte da invernada da Areia, que ao ser dividida entre os oito filhos de Antônio Waltrick, em meados da década de 1960, foi quase que imediatamente loteada e, consequentemente, deu origem aos bairros da região do Extremo-Sul da cidade de Lages, além de outros, sendo eles: São Luiz, Santa Catarina, Araucária e Cruz de Malta, todos na região Sul de Lages/SC. Inicialmente, os lotes foram comercializados sem que o loteamento tivesse infraestrutura urbana. Naquela época, os moradores contavam apenas com a escola isolada, inaugurada em 1969. As ruas foram abertas somente na década de 1970, e a rede de luz chegou em 1975, enquanto a rede de água, somente na década de 1980.

Cerca de 200 moradores chegaram ao bairro para iniciarem sua ocupação. Eram exfuncionários do $2^{\circ}$ Batalhão Rodoviário, que se mudou para o estado do Amazonas. Aquele grupo havia sido despedido, mas os que residiam nas áreas de companhias receberam como doação as casas

\begin{tabular}{l}
5 Os mapas apresentados neste estudo foram elaborados por meio do Sistema de Coordenadas Geográficas Datum: \\
SIRGAS 2000 e das Bases Geográficas do IBGE. \\
\hline Oliveira, Luchese e Ceccato, 2021 \\
ISSN 2594-9616
\end{tabular} 
em que habitavam. Essas moradias foram, então, reconstruídas, dando origem ao loteamento Santa Clara. Na Figura 4, Dona Maria do Patrocínio, primeira moradora do bairro Santa Clara, já morava no bairro quando esse movimento de ocupação aconteceu.

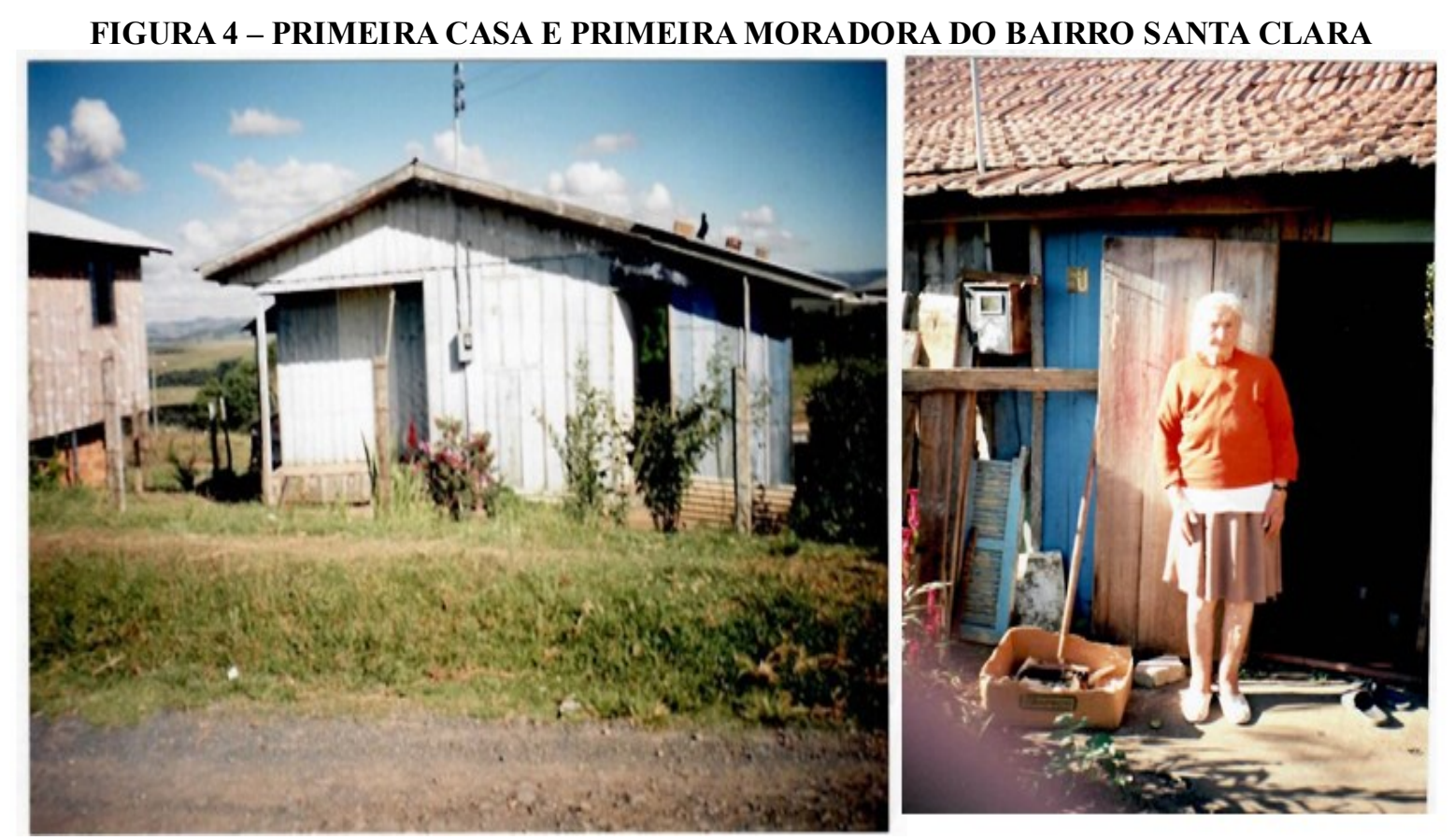

Fonte: Acervo pessoal dos moradores (2018).

Ocorre que, uma vez desempregados, muitos não conseguiam pagar as prestações dos lotes e acabaram vendendo seus imóveis. Outras famílias, que tinham escolhido aquele loteamento para morar, também deixaram o local com menos de 1 ano de residência, em consequência, principalmente, da falta de infraestrutura urbana. Sem ruas, água e luz, a vida ali era extremamente difícil. Para pegar o ônibus urbano, os moradores tinham de se deslocar até a região do Conte, no alto do bairro Santa Catarina, a cerca de dois quilômetros e meio de distância; sendo assim, esse loteamento ficou com pouquíssimas residências e quase foi extinto (CORREIO LAGEANO, 2004).

A economia do bairro voltava-se à questão da atividade agropecuária, cujos aspectos se fazem muito presentes ainda hoje, visto que, nos primeiros anos de formação, o comércio era formado por quatro bares e não existiam áreas industriais, apenas algumas chácaras nas quais se desenvolviam atividades de agropecuária, com enfoque na produção primária do leite. Ainda assim, na década de 1970, era comum, nas chácaras, o plantio de bergamota, eucaliptos e a criação de animais como cavalos, aves, porcos e gado. Essas atividades eram fonte de renda para os moradores. Com o passar 
dos anos, o bairro foi crescendo e hoje possui cerca de 1.200 moradores (IBGE, 2010) embora a infraestrutura das ruas e ambientes públicos seja bastante precária. Na Figura 5, apresentamos um gráfico com dados quantitativos referentes ao crescimento da população do bairro Santa Clara.

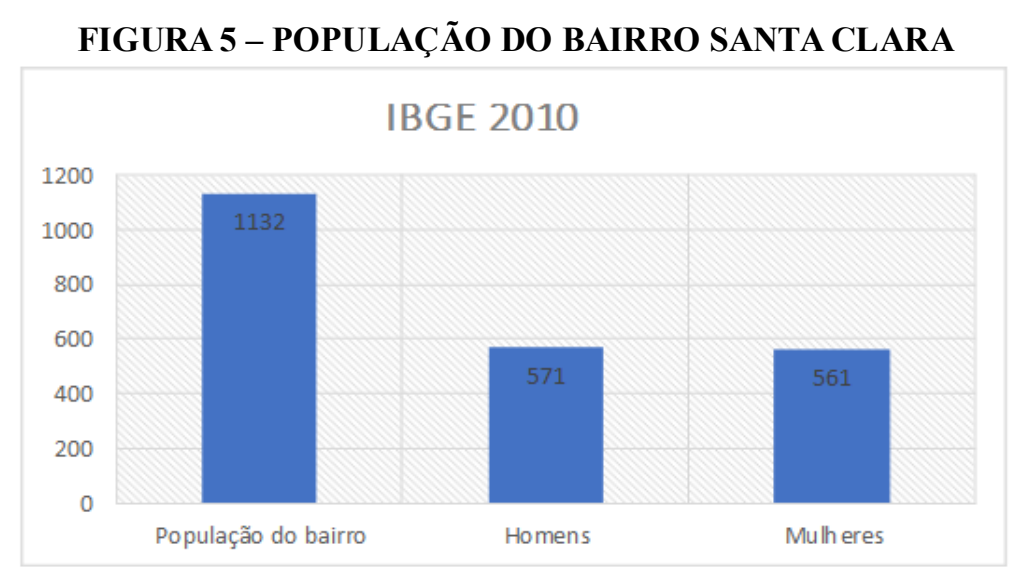

Fonte: Dados extraídos de IBGE (2010).

A Escola Municipal Cel. Manoel Thiago de Castro tem 52 anos de existência, e sua formação histórica, política e social foi sendo construída ao longo do tempo. O agrupamento de famílias que adquiriram lotes contribuiu para a formação da comunidade escolar, que, desde então, é percebida como referência. Tomamos como ponto de partida a evolução da mudança do espaço físico da escola, desde a sua fundação, apresentando registros fotográficos da sua fachada, como ponto de referência, para elucidar essas transformações. Com tudo, a Figura 6, traz a localização da Escola no Bairro. 


\section{FIGURA 6 - LOCALIZAÇÃO DA ESCOLA MUNICIPAL CEL. MANOEL THIAGO DE CASTRO}

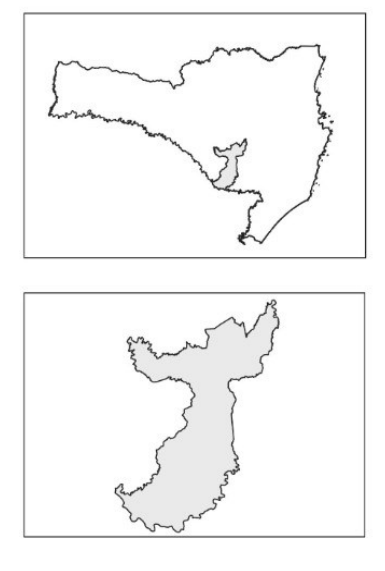

Convenções Cartográficas

- EMEB Cel Manoel Thiago de Castro

Bairro Santa Clara

Município de Lages

Estado de Santa Catarina

Sistema de Coordenadas Geográficas

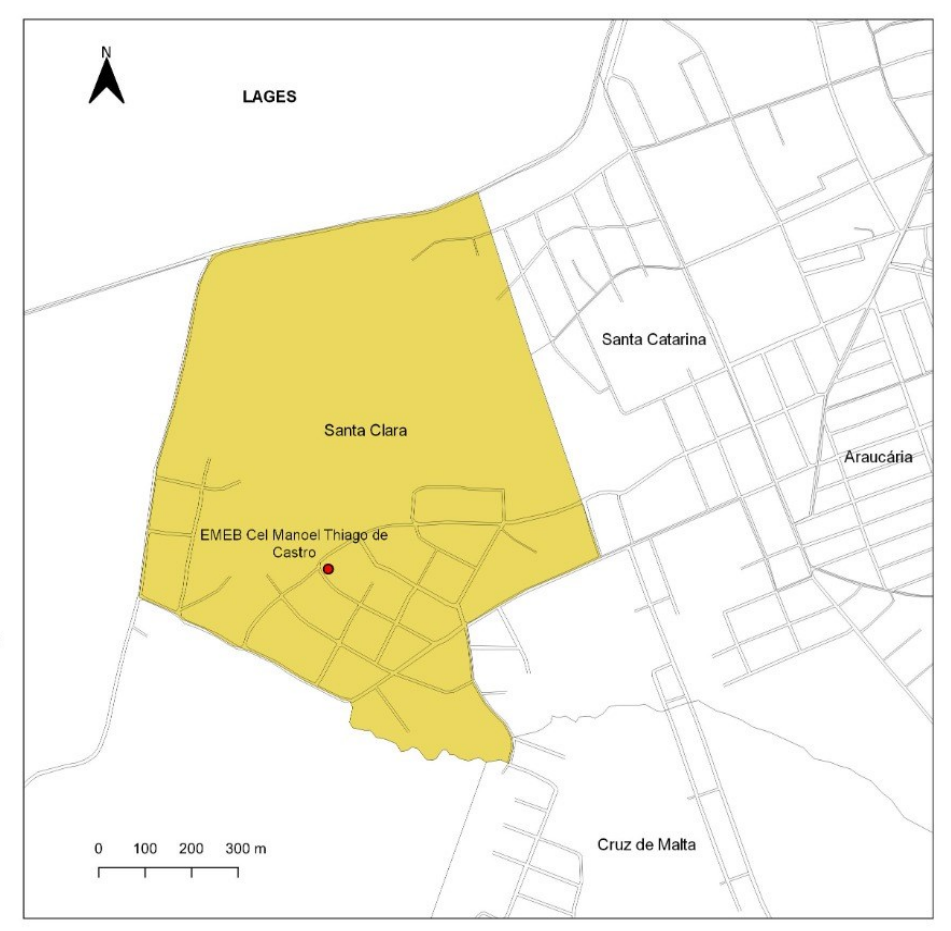

Fonte: Dados extraídos de IBGE (2019).

A paisagem, que não se dá de forma fixa, ou imóvel, como destaca Santos (1997), é resultado do movimento que a sociedade faz, em seu recorte temporal. Levando esse fator em consideração, pressupõe-se que ela não é formada somente por seus aspectos visíveis, mas também por um conjunto de ações que a transforma. Os registros que aqui serão apresentados (Figura 7 e 8) estão divididos em espaços de tempo de dez anos, em quatro imagens distintas. Destaca-se que, desde 1960, o bairro vem passando por transformações em sua paisagem. 
FIGURA 7 - FOTO DA INAUGURAÇÃO DA ESCOLA EM 1969 (REGISTRO À ESQUERDA) E FACHADA DA ESCOLA, QUE FOI CONSTRUÍDA EM ALVENARI A, EM 1980 (REGISTRO À DIREITA)

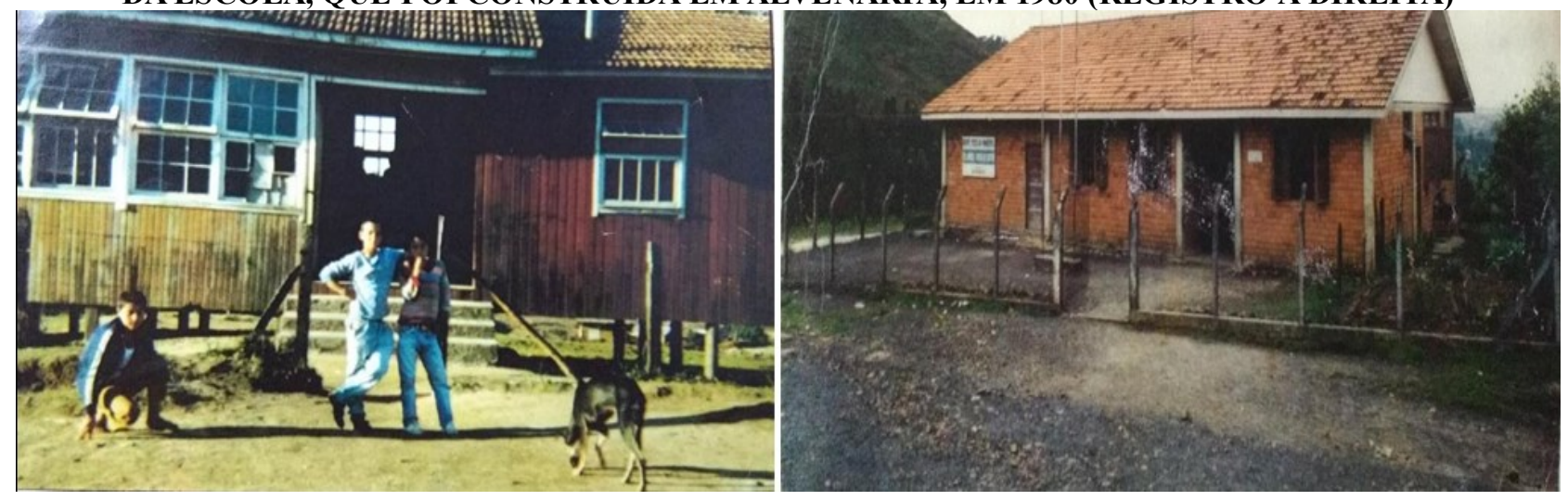

Fonte: Acervo pessoal dos moradores $(1969 ; 1980)$.

FIGURA 8 - REGISTRO FOTOGRÁFICO DE 1992, QUANDO A ESCOLA RECEBEU SUA PRIMEIRA REFORMA (REGISTRO À ESQUERDA), E FOTO DA ESCOLA EM 2001, QUANDO SEU ESPAÇO FÍSICO JÁ HAVIA SIDO AMPLIADO (REGISTRO À DIREITA)

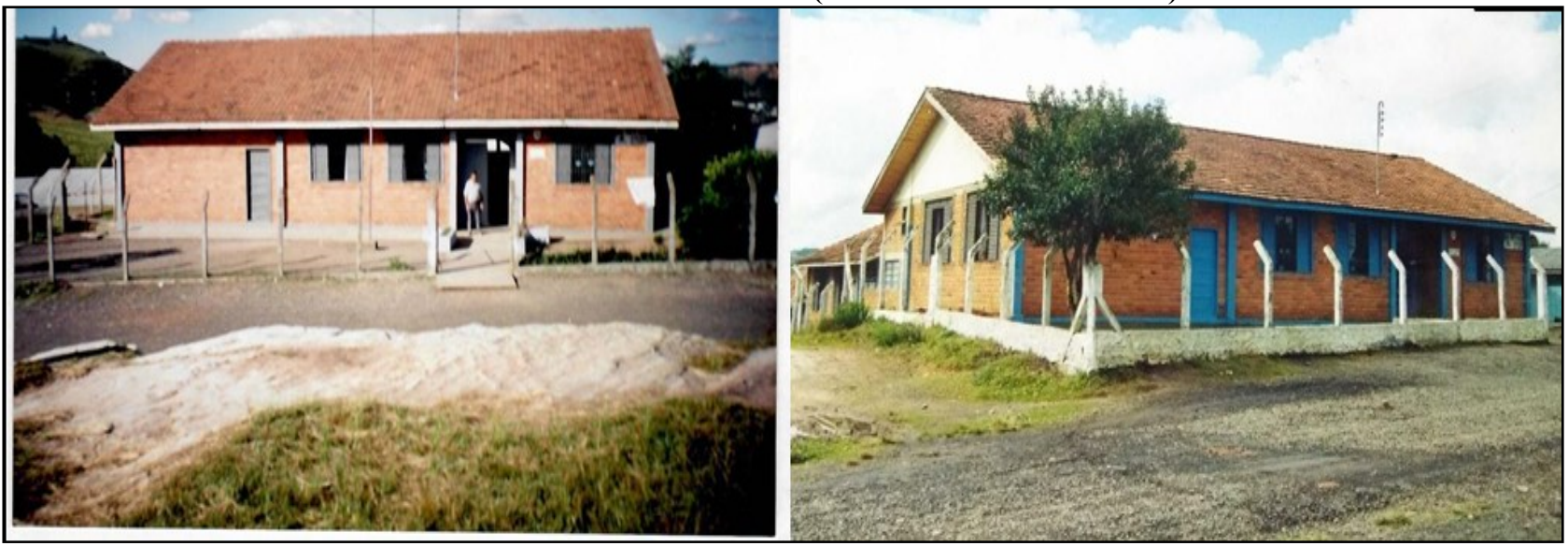

Fonte: Acervos pessoais dos moradores (1992; 2001).

Ao analisarmos o contexto histórico do crescimento do espaço físico da escola do bairro Santa Clara, percebemos não só isso, mas os elementos sociais e culturais que perpassam por essa questão. Exemplo disso foi ascendência do número de moradores no bairro, que, por consequência, aumentou a demanda de crianças e estudantes com direito e acesso à escola. Percebe-se também que o fluxo da ocupação populacional ocorreu após os anos 1970 do século XX, visto que a escola foi fundada em 1969.

Algo que é de fundamental importância para seguirmos com a apresentação dos resultados desta pesquisa é o mapeamento realizado do uso e da ocupação do espaço geográfico do bairro Santa Clara. Os espaços de tempo analisados foram as décadas de 1970 (Figura 9), 1980 (Figura 10) e 1990 (Figura 11) do século XX. A fim de apresentar uma análise mais precisa, apresentamos uma 
comparação com a área ocupada em 2010 (Figura 12). Em destaque na legenda a área urbana (em vermelho), vegetação nativa da região (em verde), e por fim, área utilizada para agricultura familiar no espaço rural (em amarelo).

\section{FIGURA 9 - USO E OCUPAÇ̃̃O DO SOLO/DÉCADA DE 1970}

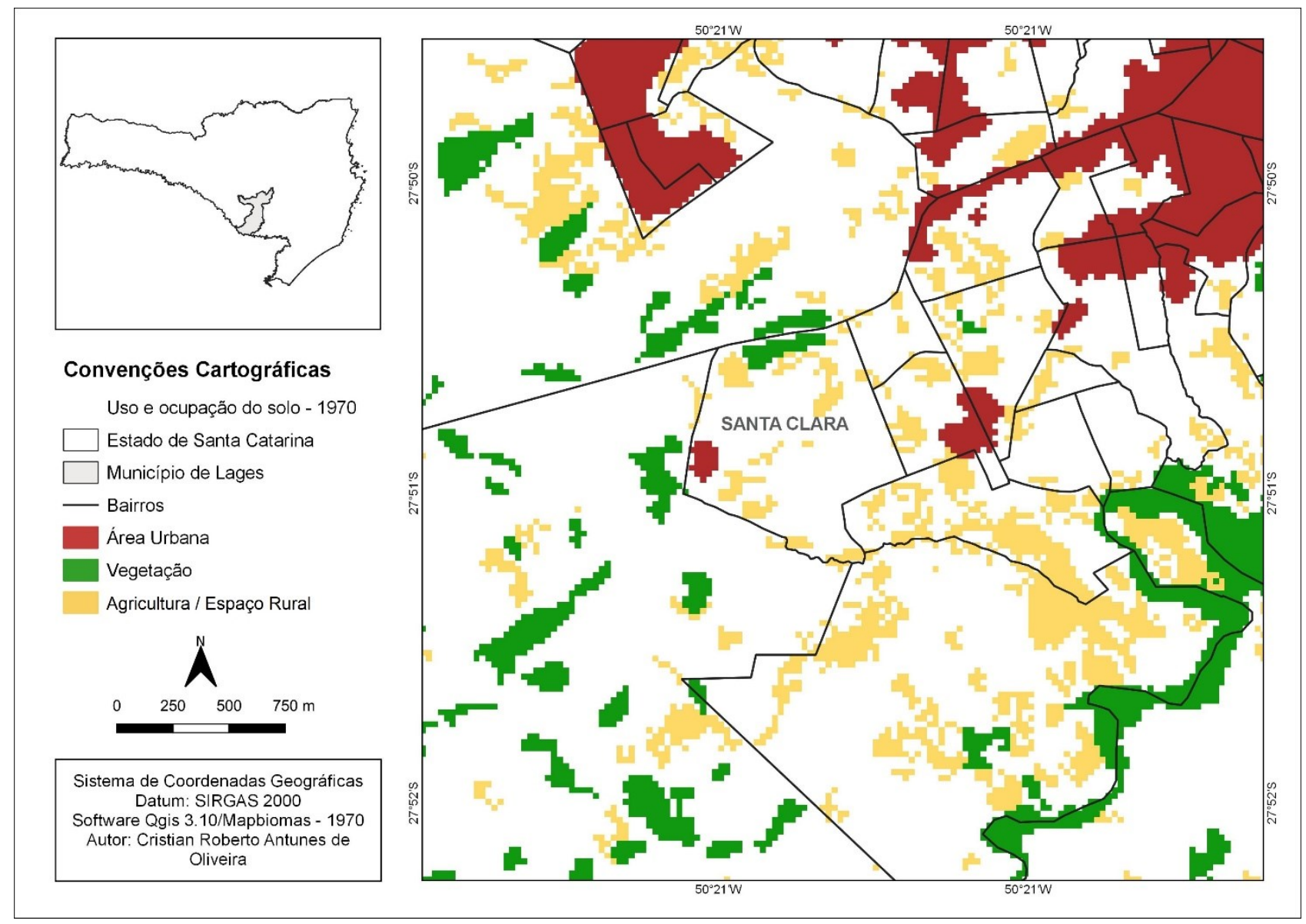

Fonte: Dados extraídos de IBGE (1970). 
FIGURA 10 - USO E OCUPAÇÃO DO SOLO/DÉCADA DE 1980

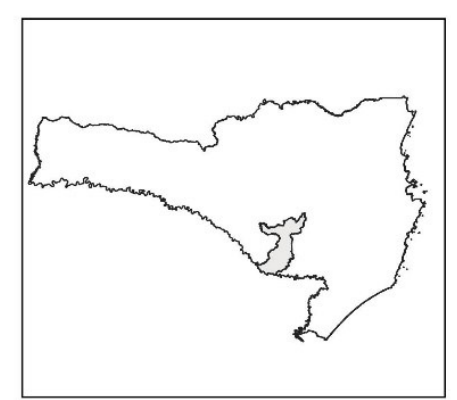

Convenções Cartográficas

Uso e ocupação do solo - 1980

Estado de Santa Catarina

Município de Lages

— Bairros

Área Urbana

Vegetação

Agricultura / Espaço Rural

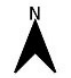

0 $250 \quad 500 \quad 750 \mathrm{~m}$

Sistema de Coordenadas Geográficas Datum: SIRGAS 2000

Software Qgis 3.10/Mapbiomas - 1980 Software Qgis 3.10/Mapbiomas - 1980
Autor: Cristian Roberto Antunes de Oliveira

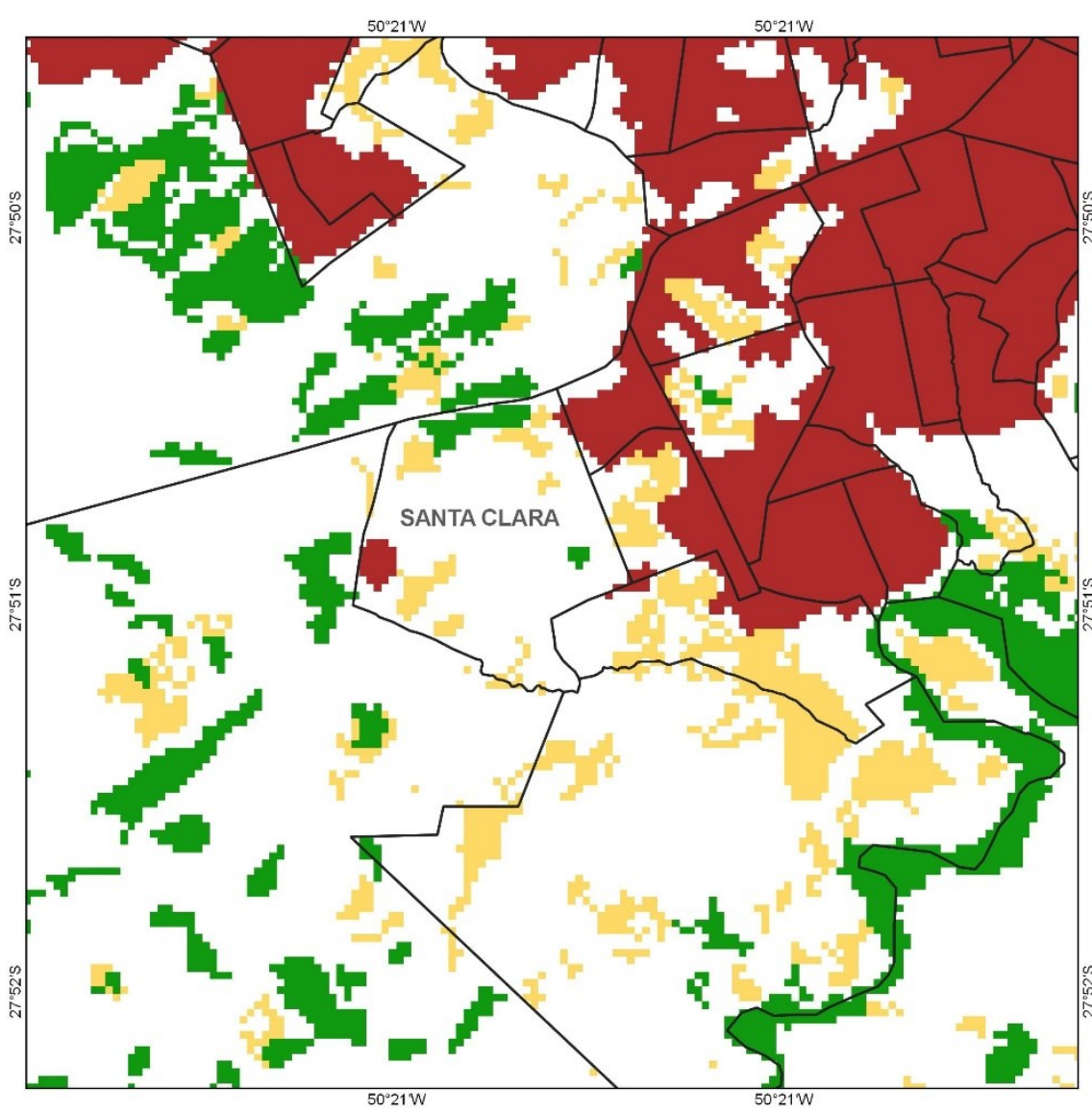

Fonte: Dados extraídos de IBGE (1980). 
FIGURA 11 - USO E OCUPAÇÃO DO SOLO/DÉCADA DE 1990

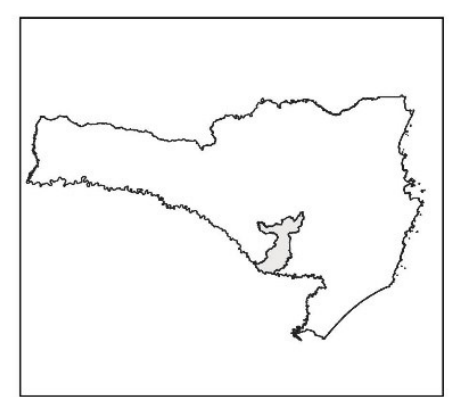

Convenções Cartográficas

Uso e ocupação do solo - 1990

Estado de Santa Catarina

Município de Lages

- Bairros

Área Urbana

Vegetação

Agricultura / Espaço Rural

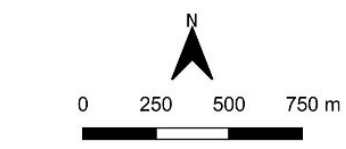

Sistema de Coordenadas Geográficas Datum: SIRGAS 2000

Software Qgis 3.10/Mapbiomas - 1990 Software Qgis 3.10/Mapbiomas - 1990
Autor: Cristian Roberto Antunes de Oliveira

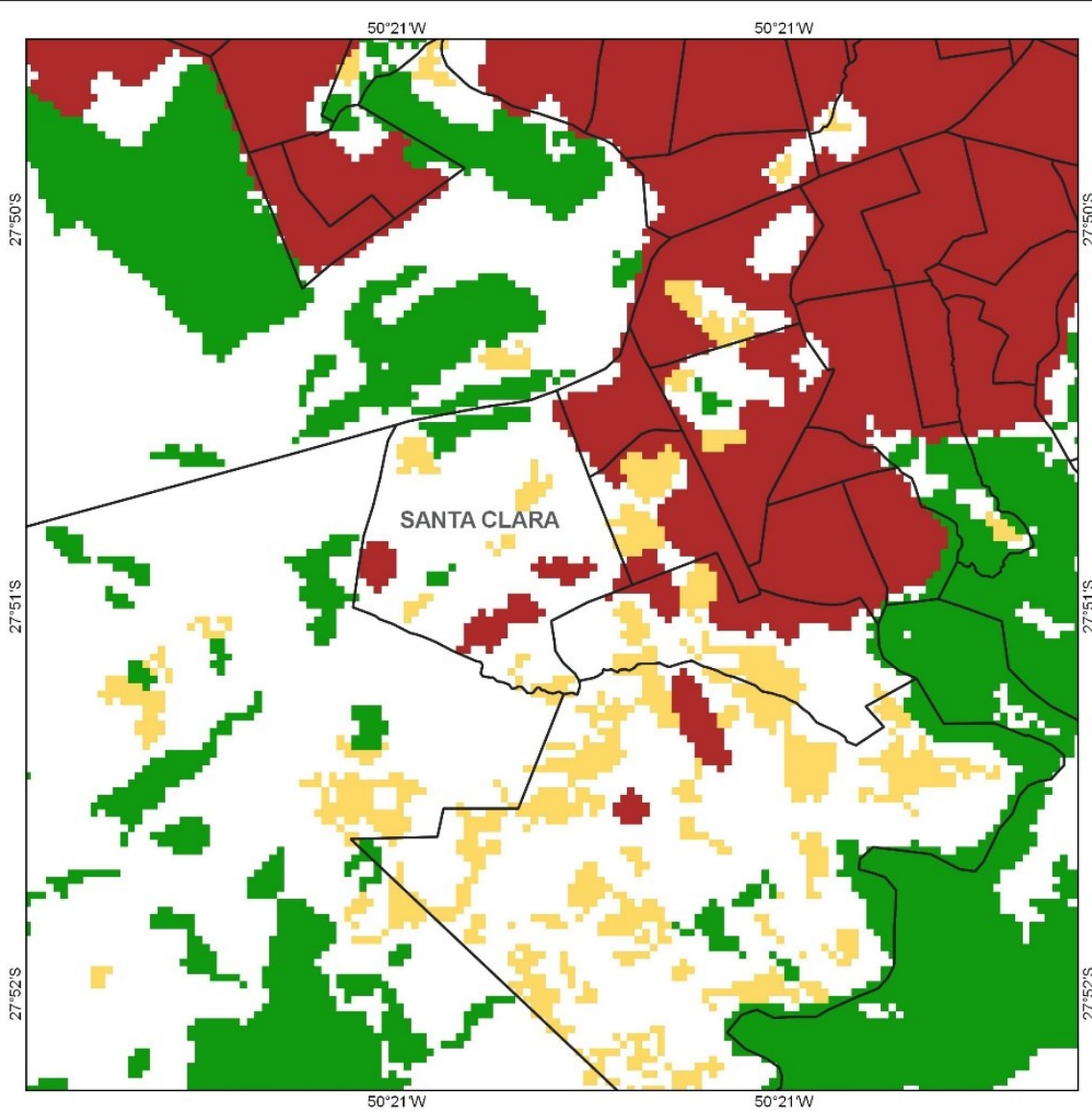

Fonte: Dados extraídos de IBGE (1990). 
FIGURA 12 - USO E OCUPAÇÃO DO SOLO/DÉCADA DE 2010

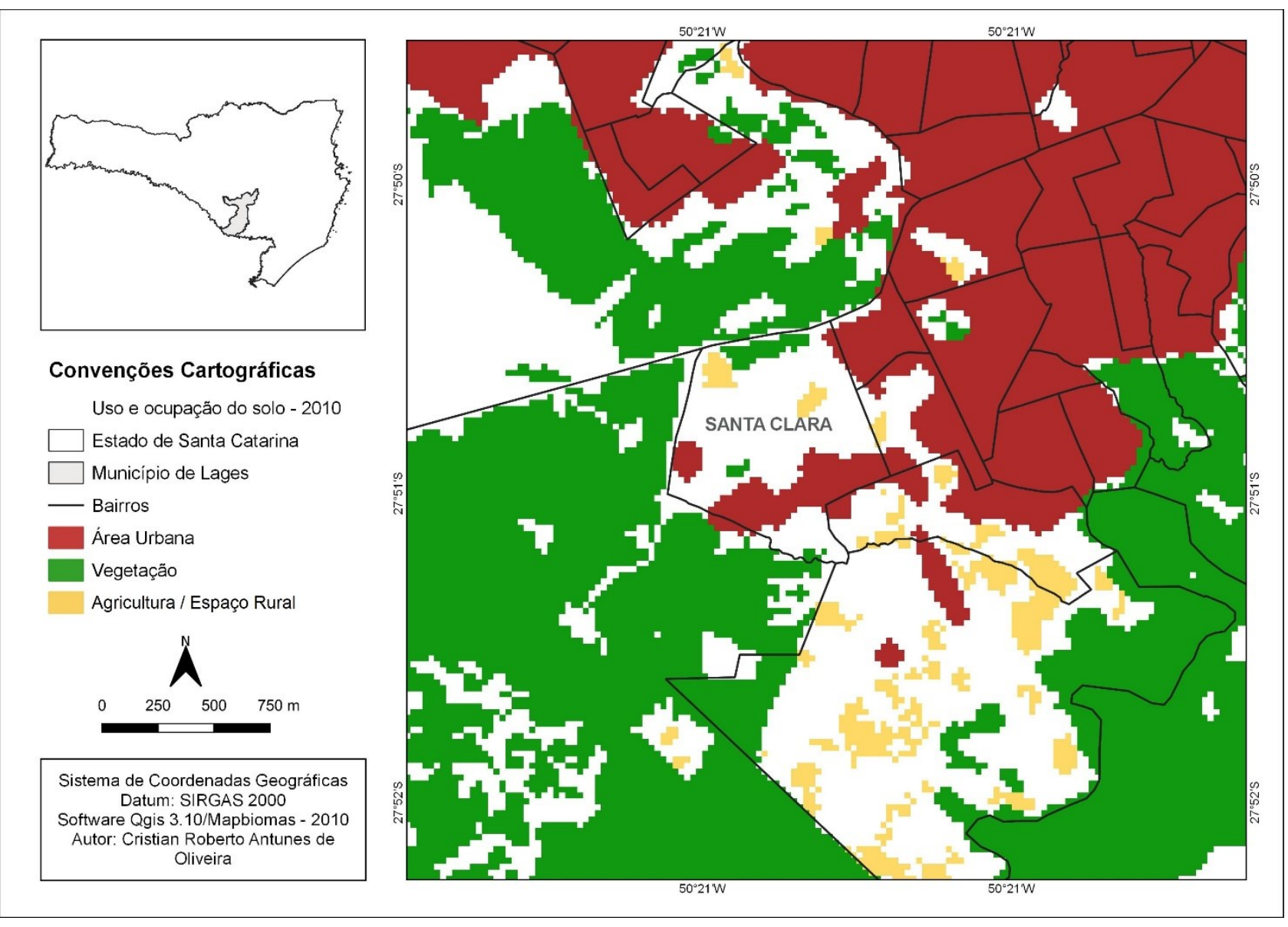

Fonte: Dados extraídos de IBGE (2010).

Também no ano de 2010, o IBGE realizou um recenseamento, e por meio dele foi possível analisar o crescimento do bairro em seus aspectos sociais e populacionais, além da ocupação urbana registrada de forma crescente nos mapas apresentados nas Figuras 09, 10, 11 e 12. O que evidencia a ampliação da mancha urbana. Quando coletamos esses dados, fizemos um panorama com o levantamento realizado em 1996 e os comparamos com os mapas produzidos pelo software QGIS 3.10 versão A Coruña. As malhas territoriais foram coletadas na plataforma digital do Instituto Brasileiro de Geografia e Estatística (IBGE).

No ano de 1996, o recenseamento apontou um número de 260 casas e uma média de três moradores por residência. Já no ano de 2008, esse número subiu para 300 casas e uma média de 900 moradores. O último dado é do ano de 2018 e foi fornecido pela associação de moradores, visto que o último censo fora realizado em 2010 (Tabela 1). Sendo assim, existe uma estimativa de 357 casas, 
e uma média de quatro moradores por residência. Segundo o censo de 2010, 92,4\% das casas são ocupadas, e 7,6\%, abandonadas por seus proprietários. Conhecer as dimensões ambientais, sociais, culturais, políticas e econômicas da realidade é fundamental, pois também é a partir delas que interpretamos os aspectos do uso e ocupação do espaço.

TABELA 1 - NÚMERO DE MORADIAS NO BAIRRO SANTA CLARA

\begin{tabular}{cc}
\hline Ano & Número de Moradias \\
\hline $\mathbf{1 9 9 6}$ & 260 \\
\hline $\mathbf{2 0 0 8}$ & 300 \\
\hline $\mathbf{2 0 1 8}$ & 357 \\
\hline
\end{tabular}

Fonte: Dados extraídos de IBGE (1990; 2010) e da Associação de Moradores do Bairro ${ }^{6}$ (2018).

O lugar, mesmo com os constantes processos de modificação, ainda conserva em seu entorno muitas áreas arborizadas. Por estar localizado na região Sul, conserva atividades da pecuária, e muitas chácaras e fazendas são mantidas nos arredores da escola. Esta questão de mescla entre espaço rural e urbano se mantém no dia a dia da comunidade, visto que muitas famílias têm cavalos em seus terrenos, vacas de leite, criação de porcos e galinhas, conforme verificado por meio da pesquisa de campo.

Nesse sentido, a questão da contaminação do solo é ainda mais preocupante. Conforme percebido por meio dos dados do recenseamento, o número de casas foi crescendo, e hoje, 65\% delas (IBGE, 2010) foram construídas em áreas irregulares, sem a menor preocupação em atender ao Plano Diretor da Cidade. Ao analisar esses dados e fontes documentais, iremos, a seguir, indexá-los com as percepções dos professores e moradores, por meio das entrevistas narrativas, fazendo um panorama do crescimento da escola no entorno do bairro com a transformação da paisagem do espaço geográfico.

Ao falar sobre a análise das entrevistas, é preciso compreender os elementos que compõem a transformação da paisagem no entorno escolar com base no Plano Diretor da Cidade de Lages, pois o uso e a ocupação do solo são elementos importantes para conhecer como as sociedades se organizam no espaço geográfico. Assim, buscamos em Takeda (2013, s./p.) a concepção de uso e ocupação do solo que tem como principais finalidades:

a) organizar o território potencializando as aptidões, as compatibilidades, as contiguidades, as complementariedades, de atividades urbanas e rurais; b) controlar a densidade populacional e a ocupação do solo pelas construções; c) otimizar os deslocamentos e melhorar a mobilidade urbana e rural; d) evitar as incompatibilidades entre funções urbanas e rurais; e) eliminar possibilidades de desastres ambientais; f) preservar o meio-ambiente e a qualidade de vida rural e urbana.

${ }^{6}$ Dados coletados no livro de registros da Associação. 
A pesquisa narrativa que aqui é apresentada aconteceu por meio de questionário para seleção dos sujeitos e, posteriormente, da entrevista narrativa com dois moradores do bairro e dois professores da escola. Neste artigo, eles serão apresentados com os seguintes descritores: Moradores (M1 e M2) e Professores (P1 e P2). A primeira pergunta que realizamos foi a fim de saber o ano em que os sujeitos da pesquisa passaram a residir no bairro Santa Clara:

Eu cheguei no bairro Santa Clara em 1975. Na época, era um bairro que não tinha quase nada, e hoje temos bastante coisa, como, por exemplo luz fácil, que na época, era mais a bateria mesmo. (M1, 2018)

Vim morar aqui no ano de 1969, com minha velha. Aqui fizemos familia, construímos nossa casa e montamos nosso bar. Fui um dos primeiros moradores do Santa Clara. (M2, 2018)

Nos relatos, é percebido que ambos possuem vivências e experiências significativas no bairro, levando em consideração o tempo que residem como moradores. Na continuidade da entrevista, buscamos aguçar a memória, perguntando sobre quais eram as percepções que tinham com relação ao crescimento do bairro Santa Clara. M1 (2018) trouxe as seguintes lembranças:

[...] um pouco só; não acho que o bairro cresceu muito. Em vista de outros, nós ficamos sempre na mesma, o que teve é mais gente vindo morar aqui dos munícipios vizinhos; por causa da BR, é mais fácil, e os lotes aqui são bem baratos, por isso que eu acho que o bairro tem mais pessoas assim. [...]. Mas quer ver? Pense comigo: só tem três ruas aqui que tem asfalto; a maioria das ruas não tem luz nos postes, $e$ a escola está bem feia, faz tempo que não passa por uma reforma. Eu acho que os políticos só passam aqui no bairro para pegar voto, depois se somem. Quer ver? Passe ali na rua da escola e veja: a escola tem mais de quarenta anos e até hoje não tem asfalto na frente. O que as pessoas fazem é tirar as árvores, invadem os lotes e fazem de tudo um pouco. É por isso que dizem que cresceu, mas não cresceu nada $[\ldots]$.

Nessa fala, percebemos a importância da percepção do espaço em que estamos inseridos, quando o morador descreve sua opinião crítica sobre o descaso do poder público. Ainda assim, as características da ocupação por meio de lotes que são comercializados por valores bem abaixo do mercado vêm ao encontro das fontes documentais. Ele retrata também, por meio da sua percepção, que o bairro não cresceu muito, devido à sua infraestrutura precária, que permanece a mesma há muitos anos.

Nesse sentido, Arruda (2008) nos leva a pensar sobre as emoções e percepções, como sendo "uma maneira de refletir sobre a nossa forma de participação no mundo". Na intenção de fazermos um contraponto, visto que a percepção se dá de diferentes formas, Maturana (2001, p. 19) enfatiza 
sua experiência quando diz que "o estudo da percepção me permitiu mudar meu modo de ver. No fundo, o que eu quero fazer é convidá-los a mudar o seu modo de ver seu olhar".

Em sua resposta, M2 diz que: "Sim, no comecinho de tudo, não tinha nada quase; tinha só três casas e a nossa. Aí foi crescendo, chegou muita gente do batalhão e veio morar aqui”. $\mathrm{O}$ entrevistado entende que houve mudança no bairro, o que nos coloca a evidência da transformação da paisagem quando fala, principalmente, do crescimento, e complementa: "Outra coisa que eu lembro é de como era a escola; de madeira, só tinha duas salas; depois foi mudando e construíram de tijolo. Acho que é isso que me lembro”. O relato sobre a mudança nos aspectos físicos da escola apresenta informações que condizem com a transformação do espaço relacionado ao território como percepção de mudança social, pois conserva em sua memória vivências fundamentais pelo fato de ele ter sido um dos primeiros moradores do bairro.

Aos professores, iniciamos perguntando quanto tempo lecionam na escola Cel. Manoel Thiago de Castro. A P1 disse: "Cheguei ao bairro no ano de 1998, e sempre fui professora. Nunca ocupei outro cargo". P2 respondeu: "Sempre atuei como professora. Os alunos me acolheram muito bem." As respostas à primeira pergunta foram diretas, sem maiores informações. $\mathrm{Na}$ continuidade da entrevista, indagamos sobre como era a escola em seus aspectos físicos e pedagógicos, quando iniciaram sua atuação profissional na escola, e as repostas foram as seguintes: "Mudou um pouco, não muito. A grande mudança neste tempo foi a construção da quadra de esportes, aguardada por muito tempo por todos nós; fora isso, nada demais. (P1, 2018). "Cheguei na escola no ano de 2013, pouca coisa mudou [...]” (P2, 2018).

As relações de espaço-tempo possibilitam verificar a totalidade social e sua organização que, segundo Santos (1997), podem ser analisadas por meio de quatro categorias: forma, função estrutura e processo. Porém, parte da humanidade ainda vive em sociedades de espaço pouco organizado pela ação do homem (MOREIRA, 2008), o que dificulta a harmonia entre o ser humano e o tempo.

Perguntamos aos moradores sobre o significado da escola para o bairro e comunidade, a fim de investigar qual a relação de pertencimento.

Sem a escola, nosso bairro não seria do jeito que é hoje. Tudo foi crescendo perto da escola; nós não temos mais nada aqui de importante que não seja a nossa escola. Aqui, tudo é dependente da escola. As festas que têm, é a escola que faz; as brincadeiras são perto da escola, tudo é na escola. Tem brechó, tem sopão, tem muita coisa que acontece ali, que a gente fica pensando: e se não tivesse o Manoel, né? E 
as professoras cuidam das crianças também, que nem nós, que precisamos da creche. Se não tem escola, como vou trabalhar? (M1, 2018)

Claro que sim, eu vim morar aqui e, depois, já construiram a escola. Na época não tinha; a mulherada da vida que fez um abaixo-assinado e pediu para um grã-fino da época fazer a escolinha. Eu logo entrei para a prefeitura e comecei a trabalhar na escola. Fui zelador, depois estudei; tinha que aprender a ler, pelo menos. Nós fazíamos muita coisa boa: sopão, feira, muita coisa que incentivava as pessoas do bairro. Ai, um dia, eu quis sair da escola, mas não deixaram, acabei ficando, me aposentei na escola. Cuidava de tudo, ajudava na merenda, na limpeza, nas pinturas. Eu fazia de tudo, era um pau para toda obra. (M2, 2018)

Os relatos apresentados destacam a importância do contexto social que a escola proporciona para a comunidade do bairro, contribuindo para a organização do espaço vivido. Essa importância vai desde oferecer a Educação Infantil para que mães possam trabalhar, o Ensino Fundamental como oportunidade de estudar, aos "sopões" que são realizados a fim de ajudar a comunidade. É certo que tais conceitos e sentidos da presença da escola estão muito além do que foi indicado ou rememorado pelos entrevistados. A escola concretizou o direito à educação.

Na visão de Santos (1997), o espaço é considerado como um fator da evolução social, contudo, não é formado apenas pelas coisas, os objetos geográficos, naturais e artificiais, presentes na natureza. Nesse sentido, além do meio natural e artificial, o espaço geográfico é constituído pela força da sociedade e de sua organização. Com isso, o pertencimento passa a ser reconhecido, pois diferentes processos emergem a partir desse sentimento, entre eles os modos de produção e organização do social e capital, que passam a influenciar em detrimento da "sobrevivência".

É por meio do lugar que expressamos nossos sentimentos, pois construímos nele memórias, e estas consolidam para o sentimento de pertencimento que nos faz reviver emoções e relações com o ambiente no qual estamos inseridos. Lugar e espaço são coisas distintas, uma vez que espaço tem a ver com uma categoria de amplitude, a fim de compreender diferentes espaços da superfície terrestre. O lugar está dentro do espaço, pois expressa elementos muito íntimos de um recorte geográfico, em seus vários aspectos, sejam eles culturais, sociais, econômicos etc.

A fim de investigarmos sobre a percepção da transformação da paisagem, perguntamos quais eram as recordações da paisagem no bairro Santa Clara: “[...] não sei direito como era, acho que era de vegetação nativa, mas não tenho certeza [...]” (M1, 2018). O M2 traz sua percepção sobre a transformação da paisagem da seguinte forma:

[...] o bairro não tinha nada, foi mudando, hoje tem para lá de 400 casas, quando cheguei aqui só tinha três. Eu acho que o bairro mudou muito; veja bem o tamanho 
que está à escola, tem até quadra! Falta posto de saúde agora, porque temos que ir ao bairro Santa Catarina, e falta arrumar essas ruas que tem muito pó. Hoje nós temos uma associação de moradores grande; eles ajudam o povo, tem um mercado grande, e umas quantas mercearias. Lá para cima está grande também; muita coisa mudou [...].

Para M2, o bairro mudou muito. A construção de casas é considerável, e essa afirmação relaciona-se aos dados do IBGE, pois apresentamos esse panorama de processo de urbanização na pesquisa documental. Ao analisar a paisagem, é possível entender o presente, por meio da interpretação das heranças passadas, e propor medidas com vistas para melhorar o futuro. Assim, Santos (2004) afirma que a paisagem exprime as heranças que representam as sucessivas relações entre homem e natureza.

Dessa forma, a paisagem do bairro foi ganhando forma diferente, conforme as mudanças ocorriam. Nesse sentido, Bertrand (2007, p. 251) compreende que paisagem não é apenas natureza, e diz:

Ela é uma criação humana, a marca de uma sociedade sobre um território. Tivemos frequentemente a tendência de esquecer que a paisagem, antes de ser um objeto de cenário e de contemplação para populações essencialmente citadinhas por sua residência e sua cultura, é historicamente uma ferramenta, campo, cidade ou fábrica, destinada a produzir bens de consumo: colheitas animais e vegetais, habitat, meio de transporte etc. Ela não é um jardim submetido ao capricho de um jardineiro imanente. Nem natural, nem artificial, mas hídrica, a paisagem não é estática.

Segundo Santos (2004, p. 66), “a paisagem existe através das formas criadas em momentos históricos diferentes, porém coexistindo com o atual, como resposta às necessidades atuais da sociedade". O espaço urbano é um lugar nosso, e um lugar nosso deve ter fechamento e proximidade de elementos, deve ser mais denso que seu entorno, e permitir a dialógica da partida e do retorno.

\section{CONSIDERAÇÕES FINAIS}

Perceber o ambiente que a escola está inserida é estar conectado com as mudanças que ocorrem o tempo todo em sua formação. É neste espaço instituído lugar que se manifestam as relações locais e que, por consequência, estão imbricadas com o sentimento de pertencimento, e também é nesse espaço que percebemos as transformações da paisagem. Ao relacionar o espaço escolar como pertencimento, é possível observar, a partir das respostas, que nesse espaço se consolida o lugar onde os sujeitos fazem a história, transformam o seu entorno e participam comumente da sociedade. 
Compreendendo essa relação, Santos (2008, p. 35) enfatiza que "lugar é um ponto do mundo onde se realizam algumas das possibilidades. É parte do mundo e se desempenha um papel na história". À vista disso, se observa a importância da escola para o bairro, a forma como percebem a sua influência para a comunidade torna este espaço o lugar de referência construído com a participação coletiva de toda a comunidade.

Por meio das entrevistas narrativas, vamos além da simples lembrança, entre o lembrar e o esquecer, considero que por meio das memórias se constitui uma viagem no tempo, e narrar é, dentre outras, rememorar experiências diversas. Tais percepções evidenciaram neste estudo vivências e experiências, adquiridas e construídas no decorrer da história de vida de cada sujeito que constituem o espaço geográfico do bairro Santa Clara, em Lages/SC. Também vimos, por meio dos registros fotográficos apresentados, do mapeamento do uso e da ocupação do espaço geográfico, que a unidade escolar passou por constantes transformações estruturais, ampliação, e mudanças de ordem ambiental, social, política e geográfica.

Conhecer o lugar onde se vive, perceber as mudanças ocorridas em nosso entorno e identificar os acontecimentos do cotidiano em relação ao meio contribui para a sociedade organizar-se no espaço geográfico, podendo, assim, fazer a diferença na comunidade local, adotando uma postura consciente, diante das questões da dinâmica de ocupação territorial. O mesmo acontece em relação ao espaço e à paisagem que se transforma para se adaptar às novas necessidades da sociedade. Desta forma, ficou evidente as transformações ocorridas no espaço geográfico do bairro Santa Clara, por meio das percepções dos professores e moradores, que discorreram em diferentes momentos do estudo, sobre particularidades das transformações que foram ocorrendo nos últimos cinquenta anos no entorno do bairro. Essa dinâmica de organização espacial pode ser percebida na forma como o bairro foi crescendo, tendo a escola como sua principal referência, seja no fomento dos aspectos sociais ou na condição de alicerce para as famílias que ali foram se estabelecendo.

Por fim, concluímos por meio das análises realizadas que sim, ocorreu a transformação da paisagem, e que esta é reflexo de um espaço temporal de mais de cinco décadas, onde as ocupações foram ocorrendo de forma desordenada, sem levar em consideração qualquer diretriz que oriente para um uso e ocupação da dinâmica espacial do solo, de forma consciente. Esses impasses contribuíram para uma transformação significativa da paisagem, esta que é produto da relação do homem com a natureza. 


\section{REFERÊNCIAS}

ADDISON, E. E. A percepção ambiental da população do Município de Florianópolis em relação à cidade. Dissertação (Mestrado em Engenharia de Produção) - Programa de Pós-Graduação em Engenharia, Universidade Federal de Santa Catarina, Florianópolis, 2003.

ALMEIDA, R. B. G.; SILVA, Daniel José. Análise de áreas mais propícias à recarga do Sistema Aquífero Guarani na região hidrográfica do planalto de Lages (SC): Subsídios para a gestão das águas subterrâneas. In: SIMPÓSIO BRASILEIRO DE RECURSOS HÍDRICOS, 19., 2011. Anais [...]. Maceió: ABRH, 2011. p. 1-20.

ANDRADE, M. C. A questão do território no Brasil. 2. ed. São Paulo: HUCITEC, 2004a.

ARRUDA, M. P. O mediador de emoções. Pelotas: Livraria Mundial, 2008.

BERTRAND, P. G. Uma geografia transversal. Paraná: Massoni, 2007.

BOLÓS, M. I. C. Problemática actual de los estudios de paisaje integrado. Revista de Geografia, Barcelona, v. 15, n. 1-2, p. 45-68, 1981.

CAVALCANTI, L. S. Geografia, escola e construção de conhecimentos. Campinas: Papirus, 2004.

CORREIO LAGEANO. Os bairros de Lages. Lages, 04 mar. 2004. p. 1-8.

CORREIO LAGEANO. Os bairros de Lages. Lages, 28 jun. 1998. p. 1-4.

FERNANDES, R. S. Entre nós, o sol: relação entre infầncia, cultura, imaginário e lúdico na educação não formal. Campinas: Mercado das Letras; São Paulo: FAPESP, 2001.

GOMES, P. C. C. Geografia e modernidade. Rio de Janeiro: Bertrand, 2000.

INSTITUTO BRASILEIRO DE GEOGRAFIA E ESTATÍSTICA (IBGE). Bases cartográficas. Rio de Janeiro: IBGE, 2019. Disponível em: https://www.ibge.gov.br/ Acesso em: 20 out. 2019.

INSTITUTO BRASILEIRO DE GEOGRAFIA E ESTATÍSTICA (IBGE). Censo 2010. Rio de Janeiro: IBGE, 2010. Disponível em: https:/ww2.ibge.gov.br/home/estatistica/populacao/ censo2010/. Acesso em: 29 ago. 2020.

INSTITUTO BRASILEIRO DE GEOGRAFIA E ESTATÍSTICA (IBGE). Características da população: classificações e identidades. Rio de Janeiro: IBGE, 1990. Disponível em: https://censo1990.ibge.gov.br/sinopse/index.php?uf=42\&dados=29. Acesso em: 29 jan. 2021.

LA BLACHE, P. V. Os Gêneros de Vida na Geografia Humana: Segundo Artigo. In: HAESBAERT, R. et al. (org.). Vidal, Vidais: textos de Geografia Humana, Regional e Política. Rio de Janeiro: Bertrand Brasil, 1982. p. 59-181.

MATURANA, H. Cognição, ciência e vida cotidiana. Belo Horizonte: UFMG, 2001.

MERLEAU-PONTY, M. O primado da percepção e suas consequências filosóficas. Campinas: Papirus, 1990.

MOREIRA, M.A. Aprendizagem significativa: ensino e geografia. São Paulo: Vetor, 2008.

RELPH, Z. C. As bases fenomenológicas da geografia. Geografia, v. 7, n. 4, p. 1-25, 1999. 
SANTA CATARINA. História. 2007. Florianópolis: Secretaria de Estado do Desenvolvimento Urbano e Meio Ambiente. Disponível em: http://www.sc.gov.br/conhecasc/historia. Acesso em: 29 ago. 2020.

SANTOS, M. A natureza do espaço: técnica e tempo - razão e emoção. São Paulo: EDUSP, 2004.

SANTOS, M. Espaço e Método. 4. ed. São Paulo: Nobel, 1997.

SANTOS, M. Metamorfose do espaço habitado. São Paulo: EDUSP, 2008.

SANTOS, M. Território globalização e fragmentação. São Paulo: Hucitec, 1994.

TAKEDA, T. O. Uso e ocupação do solo urbano. Jurisway, 2013. Disponível em: https://www.ju risway.org.br/v2/dhall.asp?id_dh=12363. Acesso em: 21 jun. 2021.

TROLL, C. A paisagem geográfica e sua investigação. Espaço e Cultura, Rio de Janeiro, n. 2, p. 17, jun. 1997. 